\title{
Study of the Physiological Behavior of Both Varieties of Bread Wheat (Triticum aestivum L) Subjected to a Metallic Stress of the Cadmium
}

\author{
Yamna Bouziani, Mabrouk Benmoussa \\ Faculty of Science of the Nature and the Life, Department of the Biotechnologies, Blida 1 University, Blida, Algeria \\ Email address: \\ bouziani.ymn@gmail.com (Y. Bouziani), benmoussa.mebrouk@yahoo.com (M. Benmoussa)

\section{To cite this article:} \\ Yamna Bouziani, Mabrouk Benmoussa. Study of the Physiological Behavior of Both Varieties of Bread Wheat (Triticum aestivum L) \\ Subjected to a Metallic Stress of the Cadmium. International Journal of Ecotoxicology and Ecobiology. Vol. 5, No. 3, 2020 , pp. 36-41. \\ doi: $10.11648 /$ j.ijee.20200503.12
}

Received: April 2, 2020; Accepted: April 22, 2020; Published: October 23, 2020

\begin{abstract}
The cadmium is one of the metallic element traces very toxic for vegetables, animals and human. Its presence in the soil is aggravated by the various cultural practices. This study is to test the effect of cadmium on the physiological parameters and its accumulation in two varieties of bread wheat (Triticum aestivum L). The relative growth of seedlings, the rate of chlorophyll $a$ and $b$, the proline, soluble sugars and rate of accumulation of Cadmium are measured under four concentrations of $\mathrm{Cd}$ staggered from 0 to $150 \mathrm{mg} / \mathrm{l}$ and tested on the varieties Arz and Hiddab. Results show an important reduction of the relative growth of the seedlings of both varieties but in a different way. A disturbance of the various physiological processes is observed a decrease of the photosynthesis gradually with the increase of the dose in cadmium on the chlorophyll $\mathrm{a}$ and $\mathrm{b}$ compared with the control, increase of the rates of the proline, the soluble sugars and the rate of cadmium in seedlings following the increase in concentration of the metal study. The Arz variety is more accumulating than Hiddab. The presence of the cadmium in the environment causes a physiological disturbance of the processes and affects dramatically the production of the biomass.
\end{abstract}

Keywords: Cadmium, Bread Wheat, the Photosynthesis, Process Physiological, Proline

\section{Introduction}

Metals and metalloids are, presents naturally in soil. The development of the industrial activity (metallurgy and chemical industries) and the agricultural activity (Pesticides, fertilizers) for the last century pulled sometimes intensive contributions of these elements which become pollutant for the environment. Even in low concentrations, they can establish a severe public health problem because of their toxicity and their organic character - accumulative [1]. Plants are exposed by two ways to heavy metals on one hand by the top parties and on the other hand by the roots. Heavy metals can be deposited on the surface of leaves and roots or penetrate into the plant. They can penetrate by the air parts there (leaves, stalks and fruits), from airborne particles, from gaseous compounds or from compounds dissolved in the water of rain or irrigation and by roots from the ground. Once taken by the plant, heavy metals can be trapped and not circulate in the plant, or then transported from the site of the absorption towards another organ.

Many studies showed that the presence of metallic elements traces and particularly the presence of $\mathrm{Cd}$ in a crop can be translated, beyond a certain limit, by the appearance of symptoms of poisoning, accompanied with an inhibition of the growth of plants, with a reduction of the photosynthetic activity and with a decrease of the absorption of nutriments [2, $3]$. Wheat is one the crop the most cultivated in Algeria and the most consumed by the population. The objective is not applied on the surface of the soil to increase the production, however with, the intensive use of fertilizers especially those of the bottom and particularly the phosphated fertilizer creates another problem which is the soil pollution by heavy metals particularly Cd; According to Szolnoki \& al, (2013) [4] The contents of cadmium in fertilizers of phosphate extend between 2 and $200 \mathrm{mg} / \mathrm{kg}$. It increases the exhibition of the plant to the stress and therefore endangers the human being 
health [5]. The most common effect of cadmium consists of a reduction of the growth of the various parts of the plant. Depending on the importance of the stress, leaves can present a chlorose due a photosynthetic reduction in pigments therefore, such as the chlorophyll $\mathrm{a}$ and the chlorophyll $\mathrm{b}$ and the carotenoids, and leads to a physiological disturbance which is expressed by an oxidative stress. According to Poghosyan \& al (2014) and Tauqeer \& al (2016) [6, 7]. The present study is to investigate the effect of this toxic element on the physiological parameters and the accumulation of $\mathrm{Cd}$ in both varieties of bread wheat.

\section{Materials and Methods}

The experiment is done in the polycarbonate greenhouse in the laboratory of the biotechnology department of Blida 1 University, during year 2016. Two varieties of common wheat (Triticumaestivum L) ARZ and Hiddab widely used by our farmers are the object of this study. Seeds supplied by the ITGC (technical Institute of the field crops) are disinfected with $2 \%$ of sodium hydrochlorite during 10 minuts then rinsed with some distilled water to eliminate the fungal contaminations. They were seeded in some compost with alveoli and irrigated by solutions charged with cadmium; 10 repetitions for each treatment of chloride of cadmium 0,50 , $100,150 \mathrm{mg} / 1$ were used. After one month of growth, we made the following measures:

\subsection{Relative Dry Biomass of Roots and Leaves}

The dry mass of the seedlings is measured with a precision balance after dehydration in a steam room at $70^{\circ} \mathrm{C}$, during 72 hours, using the following formula:

The relative growth $=$ (Mass of the treated plants / Mass of controlled plants) X 100

\subsection{Rate of the Photosynthesis}

Chlorophyll $\mathrm{a}$ and $\mathrm{b}$ are determined by using the method of [8]. Which consists in making a maceration of $0.1 \mathrm{~g}$ of fresh material of leaves in $10 \mathrm{ml}$ of a mixture of $75 \%$ of acetone and $25 \%$ of ethanol with a 80 and $40 \%$ concentration successively; 48 hours later we proceed to a reading at 645 , 663 and $470 \mathrm{~nm}$ of the optical density by spectrophotometer.

The rate of chlorophyll is determined by the following formula:

Chl a $(\mu \mathrm{g} / \mathrm{g}$ MF $)=12,7 \mathrm{x}$ DO (663) - 2,59x DO (645) $\mathrm{V} /(1000 \mathrm{x} \mathrm{W})$.

Chl b $(\mu \mathrm{g} / \mathrm{g}$ MF) $=22,9 \times$ DO (645) - 4, $68 \times$ DO (663) $x$ $\mathrm{V} /(1000 \times \mathrm{W}$.

$\mathrm{V}$ : Volume of the extracted solution and $\mathrm{W}$ the weight of the fresh material of the sample

\subsection{Dosage of the Proline}

The proline is measured according to the technique used by Monneveux \& Nemmar, (1986) [9]. The principle is the quantification of the reaction proline-ninhydrine by spectrophotometric measure. The proline is coupled with the ninhydrine by forming a colored complex. The intensity of the coloring is proportional to the quantity of proline in the sample. We proceed to the reading of the optical density of the samples with the spectrophotometer in the wavelength of $528 \mathrm{~nm}$. The determination of the content of the proline is done according to the formula:

$$
\text { Proline }(\mu \mathrm{g} / \mathrm{g} \text { MF })=\text { DO528 } \times 0.62
$$

\subsection{Dosage of the Soluble Sugars}

Total soluble sugars (saccharose, glucose, fructose, divert them methyl and polysaccharides) are dosed by the method of Dubois and Gillet, (1965) [10]. It consists in taking a $100 \mathrm{mg}$ of plant material leaves in essay tubes; we added $3 \mathrm{ml}$ of ethanol at $80 \%$ in order to extractie sugars at a room temperature during 48 hours. At the time of dosage tubes are placed in the steam room at $80^{\circ} \mathrm{C}$ with a purpuse to evaporate the alcohol. In cleaned glass tubes, we put $2 \mathrm{ml}$ of the solution to be analyzed; we added $1 \mathrm{ml}$ of phenol at $5 \%$ and $5 \mathrm{ml}$ sulphuric acid concentrate at $96 \%$ while avoiding pouring some acid. We obtain an orange yellow solution at the top, and then with a weshabed whirlpool the solution is shacked in order to homogenize the color, then placed in the bath marry for 10 to $20 \mathrm{mn}$ at a temperature of $30^{\circ} \mathrm{C}$. The determination of the content of soluble sugars is done according to the formula: Soluble Sugars ( $\mu \mathrm{g} / \mathrm{g}$ $\mathrm{MF})=\mathrm{DO} 490 \times 1.657$.

\subsection{Extraction and Dosage of the Cadmium}

The mineralization took place under an extractor fan in a jar made with teflon, masses of $0.25 \mathrm{~g}$ of every sample of dry material were weighed, by adding a volume of $7 \mathrm{ml}$ of nitric acid (HNO3) at $69 \%$ and $1 \mathrm{ml}$ of hydrogen peroxide (H2O2) at $30 \%$, Jars are hermetically closed with crowbars and left at the room temperature during one hour, afterward jars were placed in a steam room at temperature of $110^{\circ} \mathrm{C}$ during $120 \mathrm{~min}$. After cooling, samples were filtered in $50 \mathrm{ml}$ phials, affermards, jars are rinsed several times with some distilled water. Then the phials are completed with distilled water up to their capacity mark and kept in a refrigerator at $4{ }^{\circ} \mathrm{C}$ to avoid any contamination until we make the analysis by spectrophotometer of atomic absorption.

\subsection{Statistical Analysis}

The statistical analysis of the obtained results was calculated by the software SPSS (C) version 2000 for Windows TM. The comparison between the averages of the various treatments also has been, established by an ANOVA followed by the test of Tukey for the comparison of the averages. This to be able to select the concentrations having a significant impact on the germination. In addition the correlation of Pearson between the parameters in the various concentrations in cadmium was also studied. 


\section{Results}

The results of our study are represented in the table 1 which contains the averages obtained from the parameters studied under the influence of the concentration of the cadmium, by quoting: the relative dry biomass, the chlorophyll a, b, the proline, the soluble sugars and the dosage of the cadmium which are illustrated by graphs and represented in figures 1-6.

Table 1. Averages of the biomass dry seedlings (PS of seedlings, relative growth (CR \%), chlorophyll a and b, the proline, soluble sugars and rate of Cd.

\begin{tabular}{|c|c|c|c|c|c|c|c|c|}
\hline Variety & $\begin{array}{l}\text { Cd dose } \\
\mathrm{mg} / \mathrm{L}\end{array}$ & $\begin{array}{l}\text { PS des } \\
\text { plantules (g) }\end{array}$ & CR (\%) & $\begin{array}{l}\text { Ch a }(\mu g / g \\
\text { MF) }\end{array}$ & $\begin{array}{l}\text { Ch b }(\mu g / g \\
\text { MF) }\end{array}$ & $\begin{array}{l}\text { Proline } \\
(\mu \mathrm{g} / \mathrm{g} \text { MF) }\end{array}$ & $\begin{array}{l}\text { Sucressolubles } \\
(\mu \mathrm{g} / \mathrm{g} \mathrm{MF})\end{array}$ & $\begin{array}{l}\text { Taux Cd } \\
\text { (mg) }\end{array}$ \\
\hline \multirow{3}{*}{ Arz } & Témoin & $0.201^{\mathrm{b}}$ & 100 & $18,960^{\mathrm{a}}$ & $13,700^{\mathrm{a}}$ & 0.050 & 0.985 & $0.024^{j}$ \\
\hline & 50 & $0.119^{c}$ & 59,2 & $17,840^{\mathrm{b}}$ & $13,260^{\mathrm{b}}$ & $0.127^{\mathrm{b}}$ & $1.520^{\mathrm{a}}$ & $0.154^{\mathrm{e}}$ \\
\hline & 150 & $0.036^{\mathrm{f}}$ & 17,91 & $12,203^{\mathrm{f}}$ & 8,883 & $0.194^{\mathrm{a}}$ & $1.510^{\mathrm{a}}$ & $0.333^{\mathrm{a}}$ \\
\hline \multirow{3}{*}{ Hiddab } & Témoin & $0.271^{\mathrm{a}}$ & 100 & $18.433^{\mathrm{a}}$ & $12.970^{\mathrm{b}}$ & 0.034 & $0.921^{\mathrm{d}}$ & $0.025^{\mathrm{j}}$ \\
\hline & 50 & $0.115^{\mathrm{c}}$ & 46.70 & $14.000^{\mathrm{e}}$ & $9.493^{\mathrm{e}}$ & $0.081^{\mathrm{d}}$ & $1.108^{\mathrm{b}}$ & $0.120^{\mathrm{f}}$ \\
\hline & 150 & $0.069^{\mathrm{e}}$ & 25.46 & $16.140^{\mathrm{c}}$ & $11.390^{\mathrm{c}}$ & $0.067^{\mathrm{f}}$ & $1.024^{\mathrm{c}}$ & $0.192^{\mathrm{c}}$ \\
\hline
\end{tabular}

\subsection{Relative Growth}

The exposure of both varieties Arz and Hiddab to the various concentrations of $\mathrm{Cd}$ causes a decrease of the dry biomass of the seedlings; however the decrease is different for the twovarieties. Hiddab was less affected when exposed to the lowest concentration of the environment in $\mathrm{Cd}$ (50 $\mathrm{mg} / \mathrm{l}$ ) (Figure 1a) and spreads out gradually with to the increase of the concentration in $\mathrm{Cd}$ until a weight of $0.036 \mathrm{~g}$ under the concentration of $150 \mathrm{mg} / \mathrm{l}$ of $\mathrm{Cd}$.

On the other hand, the variety Hiddab registered an important reduction under the concentration $50 \mathrm{mg} / 1$ of $\mathrm{Cd}$ then the decrease will be slow with the increase of the concentration of $\mathrm{Cd}$ inthe environment (Figure 1b).

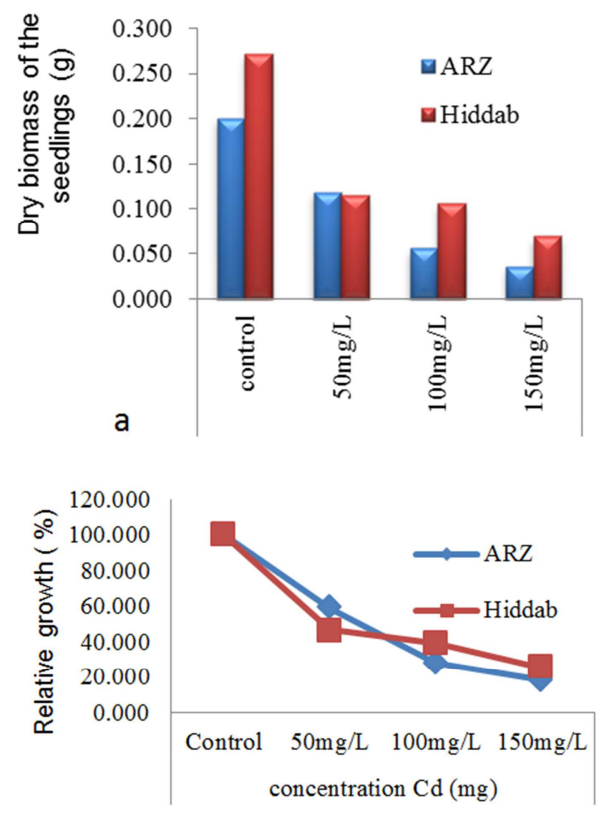

b

Figure 1. Effect of various concentrations of cadmium on the variation of the dry biomass of the seedlings of the studied varieties of bread wheat. Old seedlings 30 days were exposed to various concentrations of $\mathrm{CdCl} 2$ for 30 days. The samples were taken from each plant. The values are averages from 10 repetitions. The bars of error correspond to the standard errors.

\subsection{Chlorophyll $a$ and $b$}

The treatment by the cadmium causes a disturbance of the photosynthesis for both types ofchlorophyll $a$ and $b$ (Figure 2) in both studied varieties Arz and Hiddab. The analysis of variance revealed a very highly significant difference of this rate under the influence of the increasing doses of cadmium.
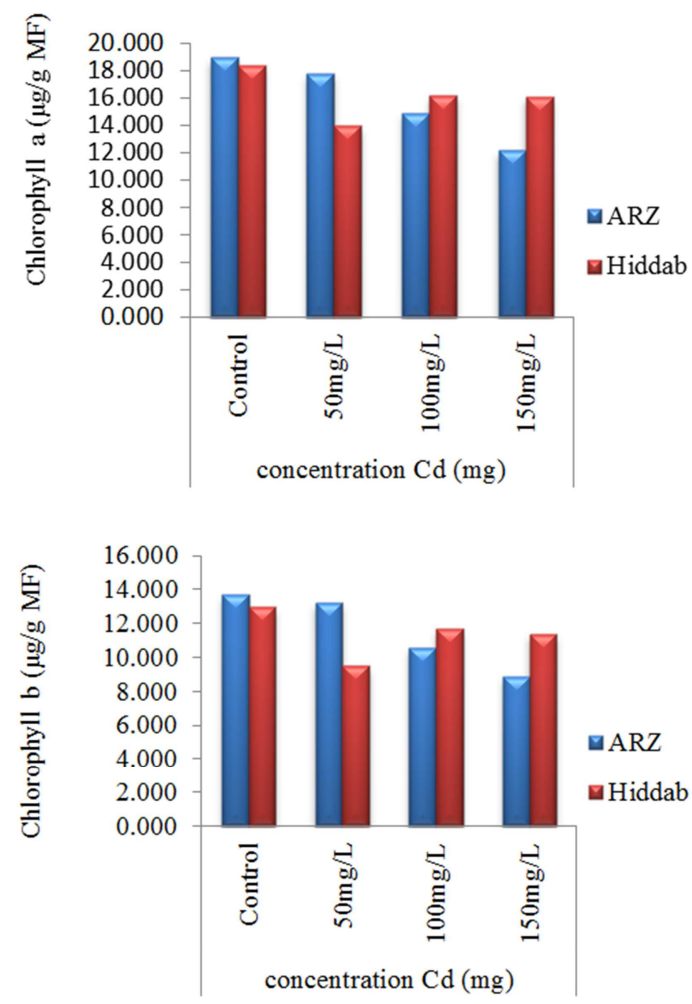

Figure 2. Effect of different concentrations of Cadmium one the assimilation of the chlorophyll $a$ and $b$. The bars of error correspond to the standard errors.

However, the rate of the chlorophyll whether it is or b decrease, gradually according to the increase of the concentration of $\mathrm{Cd}$ in the medium for the variety Arz. In this case we registered a percentage of reduction more than $60 \%$. On the other hand, the variety Hiddab behaves differently, we noted a decrease of the photosynthesis when we added $\mathrm{Cd}$ in 
the middle then, the variety took back its photosynthetic activity and kept this stability by increasing the concentration of $\mathrm{Cd}$ in the medium with rates of $(16,24 ; 11,71)$ and $(16,14$; 11,39) ( $\mu \mathrm{g} / \mathrm{g}$ MF) of chlorophyll $\mathrm{a}$ and $\mathrm{b}$ under the concentrations of 100 and $150 \mathrm{mg} / 1$ successively (Figure 2).

\subsection{Proline}

The proline is an amino acid often considered as a bio marker of stress, indeed; its dosage is to estimate the state of stress of the plant. The analysis of the variance reveals a very highly significant difference of the effect of $\mathrm{Cd}$ on the content of the proline (Figure 3 ).

The proline content increases when we added $\mathrm{Cd}$ in the environment with low concentration $(50 \mathrm{mg} / \mathrm{g})$ for varieties, however the variety Arz shows a disturbance following the increase of $\mathrm{Cd}$ in the environment $(0.127,0.111$ and 0.194 $\mu \mathrm{g} / \mathrm{g}$ MF) under the concentrations 50,100 and $150 \mathrm{mg} / \mathrm{g}$ successively. Contrary Hiddab shows a certain stability of synthesis of the proline $(0.081,0.079$ and $0.067 \mu \mathrm{g} / \mathrm{g} \mathrm{MF})$ under the concentrations 50,100 and $150 \mathrm{mg} / \mathrm{l}$ of $\mathrm{Cd}$.

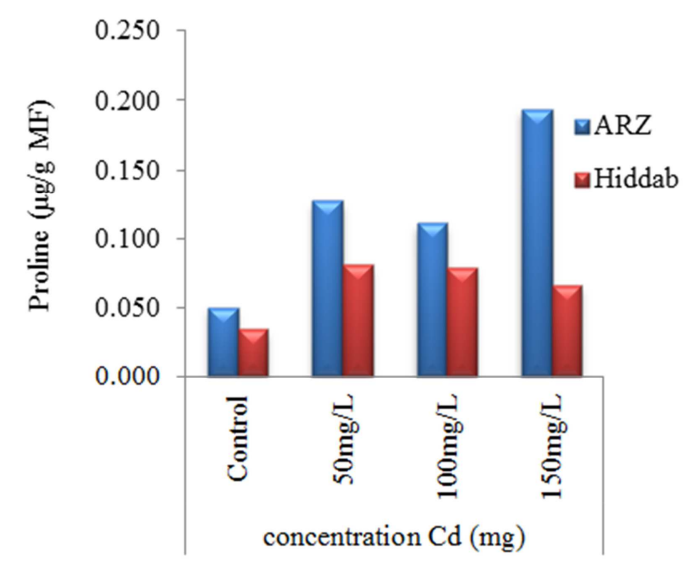

Figure 3. Effect of various concentrations of cadmium on the proline of the studied varieties of common wheat. The bars of error correspond to the standard errors.

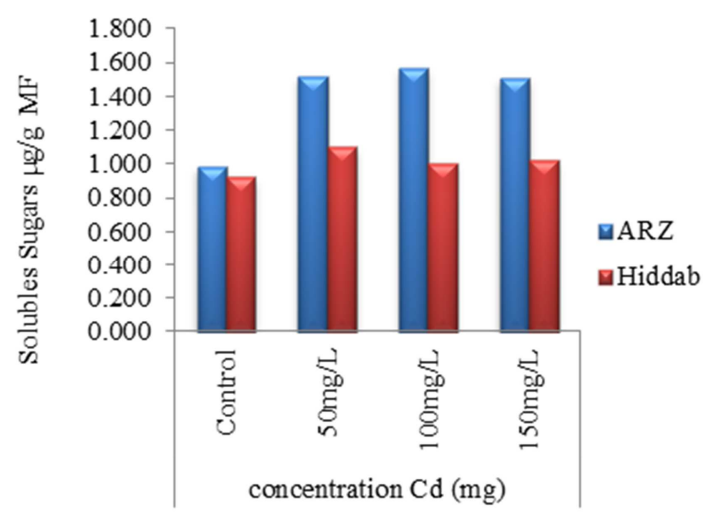

Figure 4. Effect of various concentrations of cadmium on soluble sugars of the studied varieties of bread wheat. The bars of error correspond to the standard errors.

\subsection{Soluble Sugars}

The effect of the cadmium on the contents of soluble sugars is illustrated in the figure. A very highly significant difference is recorded for the effect of $\mathrm{Cd}$ on soluble sugars, the content of the latter increases in the presence of $\mathrm{Cd}$ in the environment compared to the control where $\mathrm{Cd}$ was not added. Both subdued varieties represent the same shape for the contents in soluble sugars; however the contents registered by the variety Arz are higher than report those recorded by Hiddab (Figure 4).

\subsection{Rate of Cd}

A considerable variation of the concentration of $\mathrm{Cd}$ is registered for both varieties subjected to the various concentrations of the medium in $\mathrm{Cd}$, indeed, the analysis of the variance shows a very highly significant difference $(p=0.000)$.

The concentrations of $\mathrm{Cd}$ in the parts of the plants above the gown of the studied varieties increase according to the increase of the concentration of $\mathrm{Cd}$ in the middle, however thevarieties do not accumulate $\mathrm{Cd}$ at the same degree. Arz seems more accumulatrice than Hiddab with concentrations of 50, 100 and $150 \mathrm{mg} / 1$ successively.

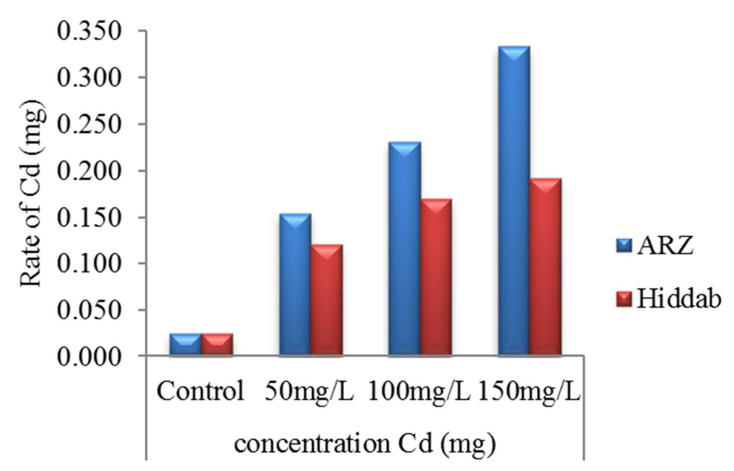

Figure 5. Effect of various concentrations of cadmium on its accumulation by the studied varieties of common wheat. The bars of error correspond to the standard errors.

\subsection{Correlation}

The test of correlation of the relative growth according to the rate of $\mathrm{Cd}$ is inversely proportional with one $\mathrm{r}=0.973$ and $\mathrm{R} 2=0.846$ (Figure 6). Indeed the growth of the seedlings of both varieties subjected to $\mathrm{Cd}$ stress decreases strongly with the accumulation of $\mathrm{Cd}$ in seedling

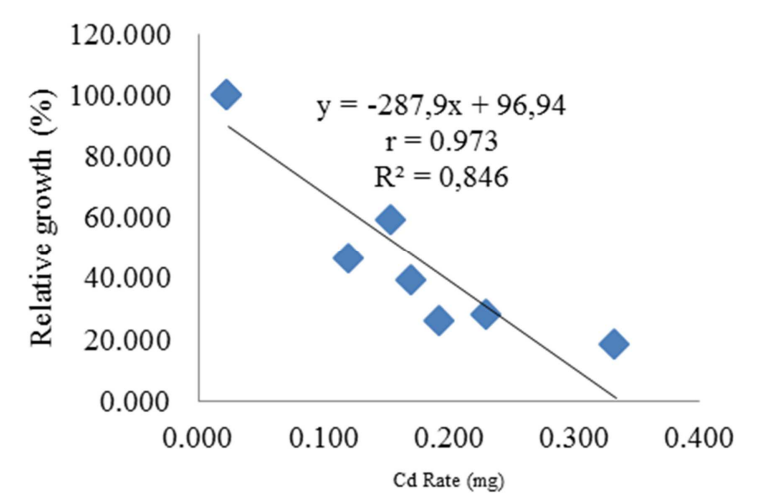

Figure 6. Correlation of the relative growth and the rate of $\mathrm{Cd}$ in the air parts of varied studied. 


\section{Discussion}

Disturbance of the photosynthetic process, the reduction of the production of the dry vegetative biomass, the induction of the synthesis of bios markers and the accumulation of the agent causing stress in the plant are the results of the presence of the cadmium in the medium of culture.

An important reduction of the vegetative biomass of both studied varieties following the increase of $\mathrm{Cd}$ in the medium is registered, the results found are similar to those several in studies on the effect of heavy metals on plants generally [11] and the effect of $\mathrm{Cd}$ on the wheat in particular [12-14]. However, the decrease is different in both varieties, the growth of the variety of whichhiddab is more affected then the Arz variety due to the trek geneticallyexplain [15].

We note a reduction of the photosynthesis expressed by the decrease of rate of chlorophyll following the increase of the concentration of cadmium as it shows several studies such as those of Moustakas and al, (1997), Singh and al, (2004) [16, 17]. Other more thorough studies were led to know the targets of actions of heavy metals in the biosynthetic way. According to Oncel and al (2000)[18], the enzymes which return in set in the presence of cadmium could prevent the formation of the complex photoassetphotochlorophyllide-NADPH-enzyme by inhibiting the protochlorophyllideréductase enzyme or stillaminolévaliniquedés-hydrogénase and it further to the interaction of the Cadmium to the thiols groupings ( $\mathrm{SH}$ ) of enzymes.

Our results are in agreement whith those found by Mobin and Khan, (2007), Ebbs and Uchil, (2008) and Ekmekci and al, (2008) [19-21], whose showed that the reduction of the photosynthesis leads automatically to a reduction in the growth of the plant.

As reported by studies done by Mujahid and al, (2013), Deyala (2016) [22, 23]; the presence of $\mathrm{Cd}$ in the environment leads to the synthesis of molecules anti oxidizing. In our research we were interested to study the variation of the rates of proline and the soluble sugars in both varieties subjected to various concentrations of $\mathrm{Cd}$ in the medium. A considerable disturbance was registered expressed by the gradual accumulation of these two molecules in tissues of seedlings [24], this accumulation results from a change of the enzymatic activities, in particular the acid invertase, saccharose synthase and the starch phosphorylase. However the rates were different in both varieties.

The assimilation of cadmium in the wheat varies with the type of soil, the atmospheric pollution and cultivated varieties of wheat $[25,26]$.

Our study was based on the factor variety. A remarkable difference of the accumulation of $\mathrm{Cd}$ is registered between both studied varieties; these results are similar to those found by Arduini and al, (2014), Ehab and al, (2013) [27, 28]. According to Adeniji and al (2010), Ci and al, (2010a) [29, 12] a higher concentration of $\mathrm{Cd}$ is accumulated in roots and less is transferred to stalks according to the wheat varieties grown.

\section{Conclusion}

In the present work, we studied the physiological behavior of two varieties of bread wheat Arz and Hiddab widely cultivated in Algeria under a range of concentration of cadmium on the physiological parameters and its accumulation in two varieties of bread wheat (Triticum aestivum $L$ ). This heavy metal is very toxic for the human being and known very to be common on these.

Our results shows that it presence in the environment leads to considerable disturbance of the physiology of both subdued varieties expressed by the decrease of the rates of chlorophyll $\mathrm{a}$ and $\mathrm{b}$ and therefore influences the production of the dry biomass of seedlings, and so active the synthesis of molecules occurring at the state of stress. However, the severity of this stress is different between both varieties; however Hiddab is shows to be more tolerant than Arz.

\section{References}

[1] Sterckeman F. Douay, N. Proix \& H. Fourrier 2008: Contamination des sols vers la profondeur à Noyelles-Godault et Auby. In: Un point sur... les éléments traces métalliques dans les sols approches fonctionnelles et spatiales. INRA. Editions. Paris. p565.

[2] Verbruggen N, Hermans C, Schat H. 2009. Mechanisms to cope with arsenic or cadmium excess in plants, Current Opinion in Plant Biology 12, 364-372.

[3] DalCorso G., Manara A., Furini A. 2013: An over view of heavy metal challenge in plants: from roots to shoots, Metallomics 5, 1117-1132.

[4] Szolnoki, Z. S; Farsang, A; Puskàs, I; 2013: Cumulative impacts of human activities on urban garden soils: origin and accumulation of metals. Environ. Pollut. 177, 106-115.

[5] Chen, C; Zhou, Q; Cai, Z; 2014: Effect of soil HHCB on cadmium accumulation and phytotoxicity in wheat seedlings. Ecotoxical 23, 1996-2004.

[6] Poghosyan, G. H; Mukhaelyan, Z. H; Vardevanyan, P. h; 2014 Influence of cadmium ions on growth and antioxidant system activity of wheat (Triticumaestivum L) Seedling. Int. J. Sci. Res. Environ. Sci. 2, 371-378.

[7] Tauqeer, H. M; Ali, S; Rizwan, M; Ali, Q; Saeed, R, Iftikhar, U; Ahmad, R; Farid, M; Abbasi, G. H; 2016: Phytoremediation of heavy metals by Alternantherabettzichiana: Growth and physiological response. Ecotoxicol. Environ. Saf. 126, 138-146.

[8] Francis et al 1970: Cooper enzymes in isolated chloroplasts. Plant Physiol, 24 1-15.

[9] Monneveux, Ph. \& Nemmar, M. 1986: Contribution à l'étude de la résistance à la sécheresse chez le blé tendre (Triticum aestivum L.) et chez le blé dur (Triticumdurum Desf.): Etude de l'accumulation de la proline au cours du cycle de développement. Agronomie, 6 (6), pp. 583-590.

[10] Dubois M., Gillet K. A. 1965: Dosage des sucres totaux à l'ortho-toluidine, J. Agr. Food Chem. 13: 137.

[11] Djebali W., Zarrouk M., Brouquisse R., El Kahoui S., Limam F., Ghorbel M. H., Chaibi W. 2005: Ultrastructure and lipid alterations induced by cadmium in tomato (Lycopersiconesculentum) chloroplast membranes. Plant Biol (Stuttg) 7: 358-368. 
[12] Ci, D; Jiang, D; Wollenweber, B; Dai, T; Jing, Q; Cao, W; 2010a: Cadmium stress in wheat seedlings: growth, cadmium accumulation and photosynthesis. Acta Physiol. Plant. 32, 365-373.

[13] Riaz, S; Iqbal, M; Hussain, I; Rasheed, R; Ashraf, M. A; Mahmood, S; Younis, M; Iqbal, M. Z; 2014: Chronic cadmium induced oxidative stress not the DNA fragmentation modulates growth in spring wheat (Triticumaestivum). Int. J. Agric. Biol. 16, 789-794.

[14] Rizwan, M; Meunier, J. D; Davidian, J. C; Pokrovsky, O. S; Bovet, N; Keller, C; 2016b: Silicon alleviates Cd stress of wheat seedlings ( Triticumturgidum L. cv. Claudio) grown in hydroponics. Environ. Sci. pollut. Res. 23, 1414-1427.

[15] Naeem, A; Saifullah, Rehman, M. Z. U; Akhtar, T; OK, Y. S; Rengel, Z; 2016: Genetic variation in cadmium accumulation and tolerance among wheat cultivars at the seedling stage. Commun. Soil. Sci. Plant Anal.

[16] MoustakasM., Lanaras, T., Symeonidis, L., Karataglis, S., 1997: Growth and some photosynthetic characteristics of field grown Avena sativa under copper and lead stress. Photosynthetica 30: 389-396.

[17] Singh K. P., Mohan, D., Sinha, S., Dalwani, R., 2004: Impact assenssment of treated/untreted wastewater toxicants discharged by sewage treatment plants on health, agricultural and environmental quality in the wastewater disposal area. Chemosphere 55: 227-255.

[18] Oncel I., Keles Y., Ustun A. S., 2000: Interactive effects of temperature and heavy metal stress on the growth and some biochemical compounds in wheat seedlings. Environ. Pollut. $107,315-320$.

[19] Mobin M, Khan NA 2007: Photosynthetic activity, pigment composition and antioxidative response of two mustard (Brassica juncea) cultivars differing inphotosynthetic capacity subjected to cadmiumstress. J Plant Physiol 164: 601-610.

[20] Ebbs S., Uchil S. 2008: Cadmium and zinc induced chlorosis in Indian mustard [Brassica juncea (L.) Czern] involves preferential loss of chlorophyll b. Photosynthetica 46: 49-55.
[21] Ekmekci Y., Tanyolac D., Ayhana B. 2008: Effects of cadmium on antioxidant enzyme and photosynthetic activities in leaves of two maize cultivars. J Plant Physiol 165: 600-611.

[22] Mujahid F; Muhammad B. S; Sana E; Shafaqat A; Muhammad Z and Muhammad A. H; 2013:Morphological, physiological and biochemical responses of different plant species to Cd stress. 3, 53-60.

[23] Deyala M, N; 2016: Enzymatic Status of Germinating Wheat Grains under Heavy Metals Stress. Inter. J. A. P. Sci. Agriculture (IJAPSA) vol 02, Issue 08, 61-69.

[24] Aoun M., 2009: Action du cadmium sur les plants de moutarde indienne Brassica juncea. Thèse de Doctorat. Université de Bretagne Occidentale, 135 p.

[25] Guo, H; Tian, R; Zhou, H; Pei, D; Wang, X; 2012: Combined cadmium and elevated ozone affect concentrations of cadmium and antioxidant systems in wheat under fully openair conditions. J. Hazard. Master. 209, 27-33.

[26] Liu, K; Lv, J; He, W; Zhang, H; Cao, Y; Dai, Y; 2015a: Major factors influencing camium uptake from the soil into wheat plants. Ecotoxicol. Environ. Saf. 113, 207-213.

[27] Arduini, A. Masoni, M. Mariotti, S. Pampana, L. Ercoli; 2014: Cadmium uptake and translocation in durum wheat varieties differing in grain-Cd accumulation. Plant Soil Environ. Vol. 60 No. 1: 43-49.

[28] Ehab M. R. Metwali, Salah M. H. Gowayed, Omar A. AlMaghrabi and Yahia Y. Mosleh, 2013:Evaluation of Toxic Effect of Copper and Cadmium on Growth, Physiological Traits and Protein Profile of Wheat ( Triticumaestivum. L), Maize (Zea mays. L) and Sorghum (Sorghum bicolor. L). World Appl. Sci. J., 21 (3): 301-314.

[29] Adeniji, B. A; Budimir-Hussey, M. T; Macfie, S. M; 2010: Production of organic acids andadsorption of $\mathrm{Cd}$ on roots of durum wheat (Triticumturgidum L. var. durum). Acta Physiol. Plant. 32, 1063-1072. 